\title{
ANALYSIS OF THE INFLUENCE OF EXTERNAL MICROENVIRONMENTAL FACTORS ON THE ACTIVITY OF MANUFACTURING PHARMACEUTICAL ENTERPRISES
}

\author{
I.V.Bondareva \\ National University of Pharmacy \\ Key words: tendencies of the pharmaceutical market; external microenvironmental factors; \\ manufacturing pharmaceutical enterprises; organizations-customers; competitors; suppliers; \\ contact audiences
}

\begin{abstract}
Today, in conditions of an increasing unpredictability, novelty and complexity of the external environment the intensification of its influence on the processes of manufacturing pharmaceutical enterprises functioning is observed. To provide survival, resistant functioning and development of pharmaceutical enterprises in the conditions of changes occurring in the external environment it is necessary to study the influence of factors of the external macro- and microenvironment and adapt to them. According to the survey of managers of different levels of fifteen domestic pharmaceutical enterprises it has been found that the main tendencies of the pharmaceutical market affecting the activity of manufacturing pharmaceutical enterprises are appearance of new medicines, expansion of the assortment, increase of the enterprises' profits and improvement of work with suppliers. The degree of the influence of suppliers, competitors, organizations-consumers and contact audience on the work of manufacturing pharmaceutical enterprises has been determined. Most microenvironmental factors positively affect the activity of enterprises. The influence of organizations-consumers, in particular their solvency, reliability and terms of delivery and the influence of suppliers (availability of exclusive offers, the assortment and quality of products, the terms of sale and the supplier's reliability) have the greatest number of positive evaluations. According to the respondents competition takes the third place by the degree of the positive influence on the activity of manufacturing enterprises. Most respondents have positively estimated the influence of contact audience on the activity of manufacturing pharmaceutical enterprises; however, some factors have received a significant number of negative evaluations, in particular the impact of public organizations, public authorities, local contact audience and mass media.
\end{abstract}

Today, in conditions of an increasing unpredictability, novelty and complexity of the external environment the intensification of its influence on the processes of manufacturing pharmaceutical enterprises functioning is observed. Instability of the economic and political situation, increased competition significantly complicate the management process, and the prospects of development become less predictable. To provide survival, resistant functioning and development of pharmaceutical enterprises in the conditions of changes occurring in the external environment it is necessary to study the influence of factors of the external macro- and microenvironment and adapt to them.

Analysis of the latest research and publications, in which the solution of the problem is initiated and which the author reffers to. In the works of well-known foreign authors the problems of management of enterprises adaptation to changes of the external environment are considered [5-10]. In scientific professional pharmaceutical journals there are articles concerning the impact of external macro- and microenvironment factors on the activity of pharmacies [1-4].

Singling out the previously unsolved parts of the general problem, which the given article is devoted to. There is almost no information in literature concerning the influence of external macro- and microenvironment fac- tors on the activity of manufacturing pharmaceutical enterprises, including analysis of the impact of organizations-customers, competitors, suppliers and contact audience.

The aim of the paper is substantiation of scientific and practical approaches to analysis of the influence of external microenvironment factors on the work of manufacturing pharmaceutical enterprises.

The methods of expert estimations, statistical and graphical methods were used in the study.

Presentation of the basic research material with complete substantiation of the research results obtained. The microenvironment of pharmaceutical organizations is the environment of direct influence, including such factors as organizations-customers, suppliers, competitors, contact audience directly affecting the activity of the organization, and they are directly affected from its operations. It is necessary to consider the impact of microenvironmental factors constantly and predict it for effective functioning of pharmaceutical organizations.

The main tendencies of the pharmaceutical market affecting the activity of manufacturing pharmaceutical enterprises (Fig.) have been determined. For this purpose leaders of various levels of fifteen domestic pharmaceutical enterprises estimated the list of the parameters proposed according to 10-point scale. According to 


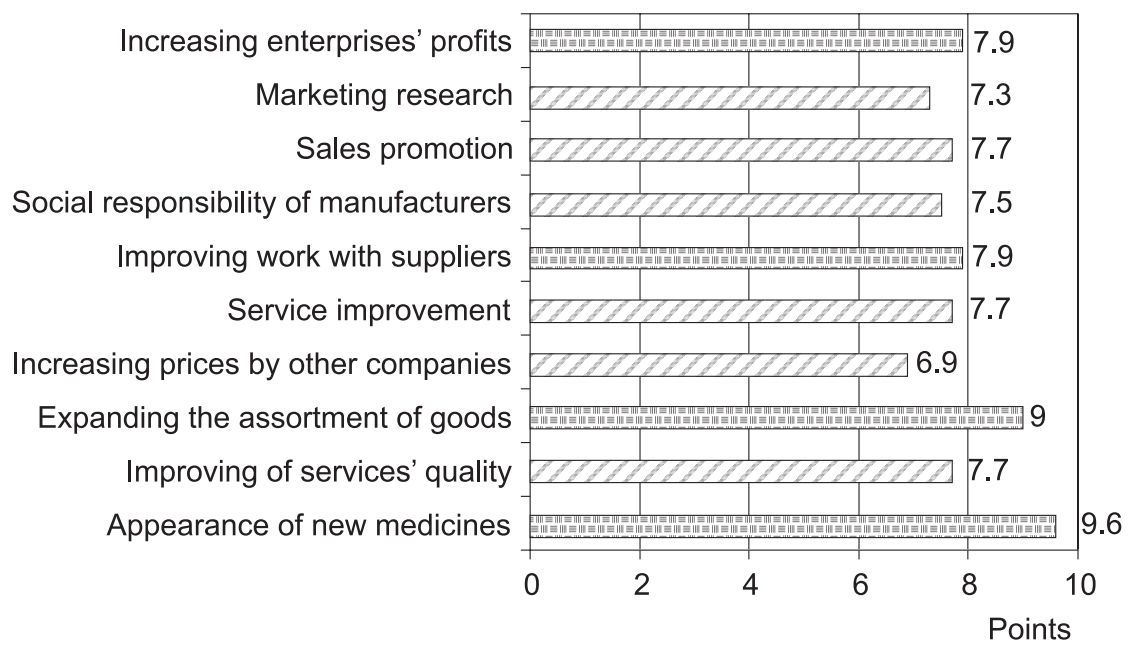

Fig. The main tendencies of the pharmaceutical market affecting the activity of manufacturing pharmaceutical enterprises.

the survey of respondents it has been found that there are the following main tendencies: appearance of new medicines, expansion of the assortment, increase of the enterprises' profits and improvement of work with suppliers; they are $9.6 ; 9.0 ; 7.9$ and 7.9 points, respectively.
Fighting for survival, increased competition, attraction of the organizations-consumers' attention to their products require manufacturing pharmaceutical enterprises to study the influence of external environmental factors for their successful functioning at the pharmaceutical market.

Table

Estimates of the degree of influence of the microenvironmental factors on the activity of manufacturing pharmaceutical enterprises

\begin{tabular}{|c|c|c|c|c|c|c|c|}
\hline \multirow{2}{*}{ Components of the microenvironmental factors } & \multicolumn{7}{|c|}{ Points } \\
\hline & -3 & -2 & -1 & 0 & +1 & +2 & +3 \\
\hline \multicolumn{8}{|c|}{ COMPETITION } \\
\hline Entry of new competitors & 6.7 & 26.7 & 13.3 & - & 33.3 & 20 & - \\
\hline Strengthening of existing competitors & 26.7 & - & - & 20 & 33.3 & - & 20 \\
\hline \multicolumn{8}{|c|}{ ORGANIZATIONS-CONSUMERS } \\
\hline Solvency & - & - & - & - & 66.6 & 6.7 & 26.7 \\
\hline Reliability & - & - & - & 6.7 & 66.6 & 26.7 & - \\
\hline Timely payments & - & - & - & 6.7 & 46.6 & 40 & 6.7 \\
\hline Terms of delivery & - & - & - & 6.7 & 66.6 & - & 26.7 \\
\hline \multicolumn{8}{|c|}{ SUPPLIERS } \\
\hline The assortment and quality of the product & - & - & - & - & 60 & 13.3 & 26.7 \\
\hline The terms of sale & - & - & - & 6.7 & 60 & 33.3 & - \\
\hline The conditions of delivery & - & - & - & 26.7 & 40 & 20 & 13.3 \\
\hline Supplier's reliability & - & - & - & 6.7 & 60 & 20 & 13.3 \\
\hline Availability of exclusive offers & - & - & - & 6.7 & 66.6 & 20 & 6.7 \\
\hline Supplier's reputation & - & - & - & 6.7 & 33.3 & 60 & - \\
\hline \multicolumn{8}{|c|}{ CONTACT AUDIENCE } \\
\hline $\begin{array}{l}\text { Financial circles (banks, investment companies, } \\
\text { brokerage firms, investors) }\end{array}$ & - & 13.3 & - & - & 40 & 26.7 & 20 \\
\hline Impact of public authorities & - & - & 26.7 & - & 53.3 & 20 & - \\
\hline $\begin{array}{l}\text { Impact of mass media (advertising agencies, } \\
\text { newspapers, magazines, radio and TV stations) }\end{array}$ & - & - & 20 & - & 53.3 & 6.7 & 20 \\
\hline $\begin{array}{l}\text { Public organizations, civic groups and other } \\
\text { groups of public opinion }\end{array}$ & - & - & 40 & 40 & 13.3 & 6.7 & - \\
\hline $\begin{array}{l}\text { Local contact audience (communities, religious } \\
\text { organizations, etc.) }\end{array}$ & - & - & 26.7 & 26.7 & 33.3 & 13.3 & - \\
\hline Own officials and employees & - & - & 6.7 & 13.3 & 66.7 & 13.3 & - \\
\hline Insurance companies & - & - & 13.3 & 46.7 & 13.3 & 26.7 & - \\
\hline Intermediaries & - & - & 6.7 & 13.3 & 60 & 6.7 & 13.3 \\
\hline
\end{tabular}


The expert evaluations were used to analyze the impact of external microenvironmental factors on the activity of manufacturing pharmaceutical enterprises. In the questionnaires managers of various levels of fifteen domestic pharmaceutical enterprises estimated the degree of the influence of microenvironmental factors using a scale from -3 to +3 . The expert assessment from -3 to -1 indicates a negative influence of the factor on the activity of the pharmaceutical enterprise, 0 - the factor doesn't affect the activity of the enterprise, from +1 to +3 indicates a positive influence of the factor. A percentage value for each factor of a certain group of the microenvironment was calculated after the data processing. The results are presented in Table. Most microenvironmental factors positively influencing on the activity of manufacturing enterprises because microenvironmental factors directly affect the activity of an enterprise and, in contrast to macroenvironment factors, they are subject to direct impact of pharmaceutical enterprises.

Analyzing the data of Table, the influence of organizations-consumers, in particular their solvency, reliability and terms of delivery, have the greatest number of positive evaluations $(+1)$.

Suppliers are one of the most important factors of the microenvironment; this fact is confirmed by the results of a survey of managers of different levels in fifteen domestic pharmaceutical enterprises. It should be noted that availability of exclusive offers, the assortment and quality of products, the terms of sale and the supplier's reliability have the greatest number of positive evaluations $(+1)$.

According to the respondents competition takes the third place by the degree of the positive influence on the activity of manufacturing enterprises Such factors as appearance of new competitors and strengthening of existing competitors received $53.3 \%$ of the respondents' positive estimates. However, $46.7 \%$ of professionals gave a negative estimate (-3 to -1$)$ to the influence of such factor of the microenvironment as appearance of new competitors, and it could be the result of unfair and illegal competition.

During the research most respondents indicated the positive influence of contact audience. However, four factors received a significant number of negative evaluations, in particular managers of manufacturing pharmaceutical enterprises estimated the impact of public organizations, public authorities, local contact audience and mass media as negative by $40 \%, 26.7 \%, 26.7 \%$ and $20 \%$, respectively, due to creation of a negative image of enterprises-manufacturers of medicines and medical products. As for $13.3 \%$ of respondents, they indicated a negative (-2) impact of banks because of instability of the banking system in Ukraine.

Thus, the results obtained at this stage of the study allow concluding that the study of the influence of the external microenvironment factors is an integral part of a successful activity of manufacturing pharmaceutical enterprises.

\section{CONCLUSIONS}

1. The main tendencies of the pharmaceutical market affecting the activity of manufacturing pharmaceutical enterprises have been found.

2 . The degree of influence of the external microenvironmental factors - suppliers, competitors, organizations-consumers and contact audience - on the work of manufacturing pharmaceutical enterprises has been determined.

\title{
REFERENCES
}

1. Громовик Б.П., Борищук В.О., Мокрянин С.М., Кухар О.О. // Фармаи. журн. - 2006. - №6.- С. 3-8.

2. Мнушко 3.М., Підліснюк I.В., Пестун I.В. // Вісник фармачії. - 2008. - №2 (54). - С. 34-37.

3. Мнушко 3.М., Бондарєва I.В. // Управління, економіка та забезпечення якості в фармації. - 2009. - №2. C. 37-42.

4. Мнушко 3.Н., Бондарева И.В. // Разработка, исследование и маркетинг новой фармачевтической продукиии: сб. науч. тр. / Под ред. М.В.Гаврилина. Пятигорская ГФА. - Пятигорск, 2008. - Bып. 63. C. 637-639.

5. Frishammar J. // Management Decision. - 2003. - Vol. 41, №4. - P. 318-326.

6. Hough J., White M. // Management Decision. - 2004. - Vol. 42, №6. - P. 781-793.

7. Karim N. // Library Review. - 2004. - Vol. 53, №7. - P. 356-362.

8. Lozada H., Calantone R. // J. of Business and Industrial Marketing. - 1996. - Vol. 11, №1. - P. 17-41.

9. Velitchka D., Weitz B. // J. of Marketing. - 2006. - Vol. 70, №1. - P. 28-35.

10. Yunggar M. // J. of American Academy of Business, Cambridge. - 2005. - Vol. 6, №2. - P. 324-331.

\author{
АНАЛІЗ ВПЛИВУ ФАКТОРІВ ЗОВНІШНЬОГО МІКРОСЕРЕДОВИЩА НА ДІЯЛЬНІСТЬ \\ ВИРОБНИЧИХ ФАРМАЦЕВТИЧНИХ ПІДПРИЕМСТВ \\ На теперішній час в умовах зростаючої непередбачуваності, новизни і складності зовнішньо- \\ го середовища спостерігається посилення їх впливу на процеси фрункціонування виробничих \\ фармацевтичних підприємств. Для забезпечення виживання, стійкого фуннкціонування та
}


розвитку фрармацевтичних підприємств в умовах змін, що відбуваються у зовнішньому середовищі, необхідно вивчати вплив фракторів зовнішнього макро- та мікросередовища та адаптуватися до них. За результатами опитування керівників різного рівня п'ятнадияти вітчизняних фрармацевтичних підприємств встановлено, що основними тенденціями фрармацевтичного ринку, що впливають на діяльність виробничих підприємств, є такі: поява нових лікарських препаратів, розширення асортименту товарів, збільшення прибутку підприємств та удосконалення роботи з постачальниками. Встановлено ступінь впливу постачальників, конкурентів, організацій-споживачів і контактних аудиторій на роботу виробничих фрармацевтичних підприємств. Більшість фракторів мікросередовища позитивно впливає на діяльність підприємств. Найбільшою кількістю позитивних оцінок відзначено вплив організаційспоживачів, зокрема, їх платоспроможність, надійність та умови поставки, а також вплив постачальників (наявність ексклюзивних пропозицій, асортимент і якість товару, умови продажів, надійність постачальника). На третьому місці за ступенем позитивного впливу на діяльність виробничих підприємств за оцінками респондентів знаходиться конкуренція. Більшість респондентів оцінила позитивно вплив контактних аудиторій на діяльність виробничих підприємств, проте деякі фрактори отримали значну частку негативних оцінок, зокрема вплив суспільних організацій, державних органів влади, місцевих контактних аудиторій та засобів масової інформації.

\section{АНАЛИЗ ВЛИЯНИЯ ФАКТОРОВ ВНЕШНЕЙ МИКРОСРЕДЫ НА ДЕЯТЕЛЬНОСТЬ ПРОИЗВОДСТВЕННЫХ ФАРМАЦЕВТИЧЕСКИХ ПРЕДПРИЯТИЙ \\ И.В.Бондарева}

Ключевые слова: тенденции фрармацевтического рынка; фракторы внешней микросреды; производственные фармацевтические предприятия; организации-потребители; конкуренты; поставщики; контактные аудитории.

Сегодня в условиях растущей непредсказуемости, новизны и сложности внешней среды наблюдается усиление ее влияния на процессы функционирования производственных фрармацевтических предприятий. Для обеспечения выживания, устойчивого ффункционирования и развития фрармацевтических предприятий в условиях изменений, происходящих во внешней среде, необходимо изучать влияние фракторов внешней макро- и микросреды и адаптироваться к ним. По результатам опроса руководителей разного уровня пятнадцати отечественных фрармацевтических предприятий установлено, что основными тенденциями фрармацевтического рынка, которые влияют на деятельность производственных предприятий, являются: появление новых лекарственных препаратов, расширение ассортимента товаров, увеличение прибыли предприятий и совершенствование работы с поставщиками. Установлена степень влияния поставщиков, конкурентов, организаций-потребителей и контактных аудиторий на работу производственных фрармацевтических предприятий. Большинство фракторов микросреды положительно влияет на деятельность предприятий. Наибольщее количество положительных оценок имеет влияние организаций-потребителей, в частности, их платежеспособность, надежность, условия поставки и влияние поставщиков (наличие эксклюзивных предложений, ассортимент и качество товара, условия продаж, надежность поставщика). На третьем месте по степени положительного влияния на деятельность производственных предприятий по оценкам респондентов находится конкуренция. Большинство респондентов оценило положительно влияние контактных аудиторий на деятельность производственных предприятий, однако некоторые фракторы получили значительную долю отрицательных оценок, в частности влияние общественных организаций, государственных органов власти, местных контактных аудиторий и средств массовой информации. 